\title{
How COVID-19 Affected Herding Behavior in the Jordanian Stock Market
}

\author{
Mohammad Elshqirat \\ Walden University
}

The main purpose of this study was to test the effect of COVID-19 pandemic on the presence of herding behavior in Amman stock exchange at market-level and at industry-level. This quantitative study covered five years and three months before the COVID-19 pandemic (from January 2015 to March 2020) and eight months during the pandemic (from May to December 2020). The cross-sectional absolute deviation (CSAD) was used to test the presence of herding in the market and in its sectors. Study results suggested that the COVID-19 pandemic has no effect on herding behavior in the Jordanian market at both market-level and industry-level.

Keywords: Amman stock exchange, behavioral finance, COVID-19, herding, industry herding

\section{INTRODUCTION}

Herding among investors in the financial markets occurs when investors imitate the investment decisions of others (Bakar \& Yi, 2016). This behavior is not constant in all times (Curto, Falcão, \& Braga, 2017) and can be affected by COVID-19 pandemic because the negative effects of the pandemic on the economy and the high uncertainty level during the pandemic may push investors to select investments based on their beliefs or to follow other investors who they think are more informed (Espinosa-Méndez \& Arias, 2021). The problem is that herding behavior carries with it risks that may make the financial market and economy instable (Rahman \& Ermawati, 2020). The specific problem is that the effect of the pandemics (like COVID-19) on the financial markets is not clear because it was studied only in a limited number of studies (Goodell, 2020). This unclarity includes the effect of pandemics on herding behavior because herding represents one attribute of the financial markets as it was concluded to exist in many markets including China (Mahmud \& Tiniç, 2018), Turkey (Akinsomi, Coskun, \& Gupta, 2018), Indonesia (Candraningrat, 2018), Pakistan (Qasim et al., 2019), South Africa and Jordan (Nasarudin et al., 2017).

The effect of the COVID-19 pandemic on herding behavior was not studied before using the same period of this study in the Jordanian financial market and thus, its unknown whether herding presence became different after announcing the pandemic. Based on this this, the main purpose of this study was to uncover the effect of the COVID-19 pandemic on herding behavior in the Jordanian stock market. Achieving the purpose of this study may help the authorities responsible for managing the financial market in anticipating the herding behavior of investors during pandemics and try to protect the market from the negative consequences of such behavior. Herding behavior was concluded to be affected by COVID-19 pandemic in many countries (Abdeldayem \& Al Dulaimi, 2020; Dhall \& Singh, 2020; Espinosa-Méndez \& Arias, 2021; Espinosa-Méndez \& Arias, 2020; Wu, Yang, \& Zhao, 2020) Because of the anticipated effect 
of the pandemic on herding behavior, the research hypotheses at market-level and at industry-level were developed assuming that the COVID-19 pandemic affected herding behavior in the Jordanian stock market.

\section{LITERATURE REVIEW}

\section{COVID-19 Pandemic and Its Economic Effects}

COVID-19 was first discovered in December 2019 in a Chinese city called Wuhan (Huang et al., 2020). After that, the virus spread rapidly all over the world which led to announce it as a pandemic by the world health organization (WHO) in March 2020 (World Health Organization, 2020). The consequences of the pandemic can be seen in all aspects of humans' life; it's affecting social life, health services, global economy, governmental performance, and many other aspects. These effects of the pandemic are increasing with the increase of the number of cases because governments tend to tighten its health protection procedures when cases are going high which means more low periods for many economic and social activities. Based on this, the effect of the pandemic can be evaluated based on the number of confirmed cases which was more than 120 million cases as on 17 March, 2021 (World Health Organization, 2021). In addition to the original virus, some variations of the virus are being discovered which may drive the effects to be worse than ever.

Pandemics like COVID-19 can affect the economy because of its huge costs (Goodell, 2020). These costs may include the cost of required health services, the cost of suspended economic activities, and the loss of postponed tourism and foreign investing activities. The pandemic affected many sectors in the economy including health, banking, education, information technology, retail, hotels, and real estate (Chaudhary, Sodani, \& Das, 2020) which may indicate that the entire economy is suffering from the severe consequences of the pandemic. By affecting all these sectors, the pandemic is also affecting financial markets because those markets reflect the decrease of economic activities and the decline in the value of the companies resulting from the pandemic.

In addition to its effects on economy, COVID-19 pandemic affected stock markets although the effect may be different in each sector (Narayan, Gong, \& Aliahmed, 2021). The pandemic affected stock prices (He, Sun, Zhang, \& Li, 2020) and markets volatility (Sharma, 2020) which means that investors are experiencing different situations where they should adapt their investing strategies to overcome the consequences of the pandemic. The pandemic changed the investors trading intensity, usage of leverage, and their number of accounts (Ortmann, Pelster, \& Wengerek, 2020). Based on these effects, the pandemic may have affected the ability of investors to take investment decisions by themselves and they may have started copying each other in the market.

\section{COVID-19 Effect on Herding Behavior}

Herding in financial markets is formed when people behave irrationally by taking the same decisions not based on the available information but rather, based on the effect of surrounding society (Campajola, Lillo, \& Tantari, 2020). This behavior can lead to destroying the financial regime through increasing the instability of the stock returns (Luu \& Luong, 2020). In addition, herding behavior may increase volatility in the market and eventually make the market inefficient (Elshqirat, 2019). This behavior is changing over time and was concluded to be different during some periods like religious occasions (Elshqirat, 2020), times of market rising and falling (Elshqirat, 2019), and times of global financial crisis (BenSaïda, Jlassi, \& Litimi, 2015). Based on this, the behavior may be changed during the time of pandemics like COVID-19.

Because the pandemic has affected everything in our life including financial markets and investors' trading activities, this effect can be extended to include herding behavior in financial markets. The pandemic increased the level of economic uncertainty in some countries (Altig et al., 2020) and this may affect investors' behavior by making them copy others when taking investment decisions (EspinosaMéndez \& Arias, 2021) which means they start to exhibit herding. The effect of the pandemic on herding behavior was evidenced by many studies all over the world. In Europe, herding behavior was concluded to be increased as a result of COVID-19 pandemic (Espinosa-Méndez, \& Arias, 2021) and the same was concluded in Australia (Espinosa-Méndez, \& Arias, 2020) and in the Arabic gulf countries (Abdeldayem 
\& Al Dulaimi, 2020). On the other side, the pandemic decreased herding among investors in China, the starting place of COVID-19, (Wu et al., 2020). In India, herding was started to appear after the pandemic at industry-level (Dhall \& Singh, 2020). In addition, herding behavior among investors was detected in the first three months of the pandemic in many countries including Jordan, United Kingdom, Russia, Malaysia, and 68 other countries as concluded by Kizys, Tzouvanas, and Donadelli (2021). In Jordan, however, no studies were conducted to study the effect of COVID-19 pandemic on herding behavior during the same period covered in this study neither at market-level nor at industry-level. This study may add value to the current literature by being the first study to test the effect of COVID-19 pandemic on investors' herding in Jordan for the period from the beginning of 2015 to the end of 2020 and by being among the few studies that test this effect at industry-level.

\section{Measuring Herding Behavior}

Herding in financial markets was measured using many different measures including cross-sectional standard deviation (CSSD) developed by Christie and Huang (1995), the cross-sectional absolute deviation (CSAD) originated by Chang, Cheng, and Khorana (2000), the measure of cross-sectional dispersion of betas by Hwang and Salmon (2004), the standardized herd measure introduced by Hwang and Salmon (2009), the measures of Lakonishok, Shleifer, and Vishny (1992), and the measure developed by Sias (2004). In this study, I utilized the measure of CSAD to detect herding in the Jordanian stock market before and during the pandemic of COVID-19. This measure is used to detect herding by considering the relationship between market return and the absolute value of the stocks' returns dispersions. The measure is calculated by first estimating the absolute deviation of the stocks returns using the following equation (Chen, 2020):

$C S A D_{t}=\frac{\sum_{i=1}^{N}\left|R_{i, t}-R_{m, t}\right|}{N}$

where CSADt is the measure of stocks returns' dispersion on day $\mathrm{t}, \mathrm{Ri}, \mathrm{t}$ is the realized return for stock $\mathrm{i}$ on day $t, R m, t$ is the average of realized returns of all stocks on day $t$, and $\mathrm{N}$ is the total number of stocks on day t.

After calculating the CSAD, the following model is used to conduct a multiple regression (Chang, Cheng, \& Khorana, 2000):

$C S A D_{t}=\alpha+\lambda_{1}\left|R_{m i, t}\right|+\lambda_{2}\left(R_{m i, t}\right)^{2}+\varepsilon_{t}$

where CSADt is the returns' dispersion calculated in Equation1, and Rmi,t is the realized return of market index on day t. The logic behind this measure is that in the absence of herding, dispersion of stocks' returns increases with the increase in market return because based on the capital asset pricing model each stock has a different beta and each beta will take its stock to different distance and/or direction from the market return. In other words, if herding behavior is absent in the market, the relationship between stocks dispersions and market realized return will be positive and linear. If herding exists among investors, they will follow each other in investment decision and thus, their stock returns will move in the same direction with each other and with the market. This means that if herding is practiced, the dispersion of stock returns will decrease with the increase in market return and this relationship may become nonlinear (Gavriilidis, Kallinterakis, $\&$ Tsalavoutas, 2016). To decide if herding exists in a given market using this measure, the parameter $\lambda 2$ should have a statistically significant negative value.

\section{Hypotheses}

Because herding behavior was concluded to be affected by COVID-19 pandemic in many countries all over the world, its hypothesized that the pandemic has affected herding behavior in the Jordanian stock market at market-level and at industry-level. In this study, two hypotheses were tested; the first hypothesis was developed to determine whether the pandemic affected the presence of herding behavior at market- 
level while the second hypothesis was formulated to examine the pandemic effect on the presence of herding at industry-level. The effect of the pandemic was examined by testing whether the presence of the behavior was the same before and during the pandemic. Study hypotheses were as follows:

H1: Presence of herding behavior at market-level is not the same before and during the pandemic of COVID-19

H2: Presence of herding behavior at sector-level is not the same before and during the pandemic of COVID-19

\section{METHOD}

\section{Research Data}

For the purposes of the study, indices and stocks prices for all listed companies in Amman stock exchange (ASE) were downloaded from the exchange website for the period from January 2015 to December 2020. Herding behavior was tested before the pandemic using the data for the period from January 2015 to March 2020 (when WHO announced the pandemic) and tested during the pandemic using data for the period from May 2020 to December 2020. Data were not available for the period from $17 \mathrm{March}$ to 9 May, 2020 because the Jordanian government decided to close the market during this time. To calculate market and sector returns, ASE free float index for the market and for each sector was used. To test the second hypothesis related to herding at industry-level, the behavior was tested in the three sectors of ASE namely: financial sector, services sector, and industrial sector for the same period of the study. Collected data were analyzed using the ordinary least squares method (OLS).

\section{Research Design}

Following most of previous studies, a quantitative design was utilized in this study to test herding in the Jordanian stock market. The main objective was to examine the effect of COVID-19 pandemic on the presence of herding behavior. This objective was approached by testing if herding existed before the pandemic and then test it again during the pandemic. The existence of herding was tested by examining the relationship between the dependent variable of cross-sectional absolute deviation for market and sectors (CSAD) and the independent variables of absolute value and squared value of market and sectors index return.

\section{Variables Definitions}

Average of realized returns of stocks in the market $(\mathrm{Rm}, \mathrm{t})$ : is the simple average of returns for all stocks in the market on day $\mathrm{t}$.

Average of realized returns of stocks in the sector $(\mathrm{Rms}, \mathrm{t})$ : is the simple average of returns for all stocks in each sector on day $t$.

Cross-sectional absolute deviation (CSAD) for the market: is a measure of the market stocks' returns dispersion from its average introduced by Chang et al. (2000) and calculated as follows:

$$
\operatorname{CSAD}_{t}=\frac{\sum_{i=1}^{N}\left|R_{i, t}-R_{m, t}\right|}{N}
$$

where CSADt is the measure of stocks returns' dispersion on day $\mathrm{t}, \mathrm{Ri}, \mathrm{t}$ is the realized return for stock $\mathrm{i}$ on day $t, R m, t$ is the average of realized returns of all stocks on day $t$, , and $\mathrm{N}$ is the total number of stocks on day t.

Cross-sectional absolute deviation for each sector (CSADs): is a measure of each sector stocks' returns dispersion from its average and calculated as follows: 
$C S A D_{s t}=\frac{\sum_{i=1}^{N}\left|R_{i, t}-R_{m s, t}\right|}{N}$

where CSADst is the measure of stocks returns' dispersion in each sector on day $\mathrm{t}, \mathrm{Ri}, \mathrm{t}$ is the realized return for stock $\mathrm{i}$ on day $\mathrm{t}, \mathrm{Rms}, \mathrm{t}$ is the average of realized returns of all stocks in the sector on day $\mathrm{t}$, and $\mathrm{N}$ is the total number of stocks in the sector on day $t$.

Realized return of market index (Rmi,t ): is the return on Amman stock exchange index on day t. this return was calculated using the following equation:

$R_{m i, t}=\left[\frac{P_{m i, t}-P_{m i, t-1}}{P_{m i, t-1}}\right] * 100$

where Pmi,t is the closing price of the index on day $t$ and Pmi,t-1is its closing price on day $t-1$.

Realized return of sector index $(\mathrm{Rmis}, \mathrm{t})$ : is the return on each sector index and calculated as follows:

$R_{m i s, t}=\left[\frac{P_{m i s, t}-P_{m i s, t-1}}{P_{m i s, t-1}}\right] * 10$

where Pmis,t is the closing price of the sector index on day $t$ and Pmis,t- 1 is its closing price on day $\mathrm{t}-1$.

Realized return of stock $(\mathrm{Ri}, \mathrm{t})$ : is the realized return on stock $\mathrm{i}$ on day $\mathrm{t}$ and calculated as follows:

$R_{i, t}=\left[\frac{P_{i, t}-P_{i, t-1}}{P_{i, t-1}}\right] * 100$

where $\mathrm{Pi}, \mathrm{t}$ is the closing price of the stock $\mathrm{i}$ on day $\mathrm{t}$ and $\mathrm{Pi}, \mathrm{t}-1$ is the closing price of that stock on the previous day.

\section{RESULTS}

\section{Descriptive Statistics}

As on December 31st, 2020, the total number of listed companies in ASE was 104. These companies belong to three sectors: financial sector (62 companies), services sector (22 companies), and industrial sector (20 companies). About $60 \%$ of listed companies are financial companies and the percentage of services and industrial companies is almost the same (21\% and 19\% respectively). Descriptive statistics about the study variables are illustrated in Table 1.

TABLE 1

DESCRIPTIVE STATISTICS ABOUT STUDY VARIABLES BEFORE AND DURING COVID-19 PANDEMIC

\begin{tabular}{|l|c|c|c|c|}
\hline \multirow{2}{*}{ Variable } & \multicolumn{2}{|c|}{ Before the pandemic } & \multicolumn{2}{c|}{ During the pandemic } \\
\cline { 2 - 5 } & Mean\% & $\begin{array}{c}\text { Standard } \\
\text { deviation\% }\end{array}$ & Mean\% & $\begin{array}{c}\text { Standard } \\
\text { deviation\% }\end{array}$ \\
\hline CSAD $_{\mathrm{t}}$ & 0.991 & 0.235 & 0.997 & 0.221 \\
\hline CSAD financial sector $^{\prime}$ & 1.018 & 0.312 & 1.083 & 0.282 \\
\hline CSAD services sector & 0.945 & 0.427 & 0.886 & 0.341 \\
\hline CSAD industrial sector & 1.073 & 0.431 & 1.034 & 0.298 \\
\hline Absolute value of market index returns & 0.293 & 0.305 & 0.354 & 0.327 \\
\hline Absolute value of financial sector index returns & 0.292 & 0.313 & 0.381 & 0.384 \\
\hline Absolute value of services sector index returns & 0.383 & 0.387 & 0.552 & 0.478 \\
\hline Absolute value of industrial sector index returns & 0.568 & 0.643 & 0.284 & 0.273 \\
\hline
\end{tabular}




\section{Hypotheses Testing}

Regression Assumptions and Stationarity Test

Before conducting the regression analysis to test the presence of herding behavior, regression assumptions were tested. The results for market and sectors data indicated that its normal, homoscedastic, and free of multicollinearity. Because non-stationarity can cause spurious regression (Ventosa-Santaularia, 2009), study variables were tested for stationarity before and during the pandemic. I tested stationarity using Augmented Dickey-Fuller test. The null hypothesis for this test is that the data are non-stationary and the alternative hypothesis is that the data are stationary. The test results indicated that for all study variables (CSAD for market and sectors, absolute value of each index returns, and squared value of each index returns) $p=.010$ which is smaller than significance level of 5\%. These results mean that time series for all variables are stationary.

\section{Hypothesis One}

The first hypothesis was developed to test whether the presence of herding behavior in ASE at marketlevel was changed due to the pandemic of COVID-19. This hypothesis was tested using the following model:

$$
\begin{aligned}
& \operatorname{CSAD}_{t}=\alpha+\lambda_{1} D^{\text {covid }}\left|R_{m i, t}\right|+\lambda_{2}\left(1-D^{\text {covid }}\right)\left|R_{m i, t}\right|+\lambda_{3} D^{\text {covid }}\left(R_{m i, t}\right)^{2}+ \\
& \lambda_{4}\left(1-D^{\text {covid }}\right)\left(R_{m i, t}\right)^{2}+\varepsilon_{t}
\end{aligned}
$$

where CSADt is the returns' dispersion calculated in Equation 1, Rmi,t is the realized return of market index on day t, and $D^{\text {covid }}$ is a dummy variable that equals zero for the period from January 2015 to March 2020 and one for the period from May to December 2020. If herding exists among investors during (before) the pandemic, $\lambda_{3}$ and $\left(\lambda_{4}\right)$ will have a negative and significant values. The first null hypothesis was that the presence of herding behavior at market-level is the same before and during the pandemic of COVID-19 and the alternate hypothesis was that the presence of herding behavior at market-level is not the same before and during the pandemic of COVID-19. As shown in Table 2 , the values of $\lambda_{3}$ and $\lambda_{4}$ were positive which indicates that herding behavior was absent at market-level before and during the pandemic (the same) or in other words, the COVID-19 pandemic did not change the presence of herding behavior among investors in the Jordanian stock market. Based on this, the null hypothesis cannot be rejected $\lambda_{3}=0.137, p=.140, \lambda_{4}$ $=0.034, \mathrm{p}=.021$

\section{TABLE 2}

\begin{tabular}{|c|c|c|c|}
\hline \multicolumn{4}{|c|}{$\begin{array}{l}\text { Panel A: Regression results at market-level for the period from January 2015- March 2020(before } \\
\text { pandemic) }\end{array}$} \\
\hline Details & Value & $t$ statistics & $P$ value \\
\hline$\alpha$ & 0.934 & 93.958 & .000 \\
\hline$\lambda_{2}$ & 0.174 & 5.294 & .000 \\
\hline$\lambda_{4}$ & 0.034 & 2.310 & .021 \\
\hline Adjusted R square & \multicolumn{3}{|l|}{.095} \\
\hline \multicolumn{4}{|c|}{$\begin{array}{l}\text { Panel B: Regression results at market-level for the period from May 2020- December } 2020 \text { (during } \\
\text { pandemic) }\end{array}$} \\
\hline Details & Value & $t$ statistics & $P$ value \\
\hline$\alpha$ & 0.981 & 30.224 & .000 \\
\hline$\lambda_{1}$ & -0.044 & -0.340 & .734 \\
\hline$\lambda_{3}$ & 0.137 & 1.484 & .140 \\
\hline Adjusted R square & \multicolumn{3}{|l|}{.039} \\
\hline
\end{tabular}

\section{RESULTS OF REGRESSION ANALYSIS FOR HYPOTHESIS ONE}




\section{Hypothesis Two}

Hypothesis two was formulated to test if COVID-19 has changed the presence of herding behavior among investors in the Jordanian stock market at sector-level. The model for this hypothesis was as follows:

$C S A D_{s t}=\alpha+\lambda_{1} D^{\text {covid }}\left|R_{\text {mis }, t}\right|+\lambda_{2}\left(1-D^{\text {covid }}\right)\left|R_{\text {mis }, t}\right|+\lambda_{3} D^{\text {covid }}\left(R_{\text {mis }, t}\right)^{2}+$

$\lambda_{4}\left(1-D^{\text {covid }}\right)\left(R_{\text {mis }, t}\right)^{2}+\varepsilon_{t}$

where CSADst is the sectors returns' dispersion calculated in Equation 4, Rmis,t is the realized return of sector index on day $\mathrm{t}$, and $D^{\text {covid }}$ is a dummy variable that equals zero for the period from January 2015 to March 2020 and one for the period from May to December 2020. The null hypothesis here was that the presence of herding behavior at sector-level is the same before and during the pandemic of COVID-19 and the alternate hypothesis was that the presence of herding behavior at sector-level is not the same before and during the pandemic of COVID-19. The same rule for $\lambda_{3}$ and $\lambda_{4}$ applies here; if these values were negative and significant, then herding exists in the sector, if not then herding is absent. The regression results for hypothesis two are summarized in Table 3 . It can be noted from the table that all values of $\lambda_{3}$ and $\lambda_{4}$ were positive except for $\lambda_{4}$ of industrial sector which was negative but insignificant $\lambda_{4}=-0.008, p=.561$. This means that the null hypothesis for all sectors cannot be rejected and that herding was absent for all market sectors before and during the pandemic. To sum up, the pandemic did not affect the existence of herding behavior among investors in all sectors of the Jordanian stock market when studied separately.

TABLE 3

\section{RESULTS OF REGRESSION ANALYSIS FOR HYPOTHESIS TWO}

\begin{tabular}{|c|c|c|c|}
\hline Details & Value & $t$ statistics & $P$ value \\
\hline \multicolumn{4}{|c|}{ Financial sector (before pandemic) } \\
\hline$\alpha$ & 0.966 & 72.624 & .000 \\
\hline$\lambda_{2}$ & 0.154 & 3.464 & .001 \\
\hline$\lambda_{4}$ & 0.043 & 2.094 & .036 \\
\hline \multicolumn{4}{|l|}{ Adj. $\mathrm{R}^{2} \quad .054$} \\
\hline \multicolumn{4}{|c|}{ Financial sector (during pandemic) } \\
\hline$\alpha$ & 1.028 & 26.657 & .000 \\
\hline$\lambda_{1}$ & 0.121 & 0.891 & .374 \\
\hline$\lambda_{3}$ & 0.031 & 0.382 & .703 \\
\hline Adj. $\mathrm{R}^{2} \quad .041$ & & & \\
\hline \multicolumn{4}{|c|}{ Services sector (before pandemic) } \\
\hline$\alpha$ & 0.888 & 43.754 & .000 \\
\hline$\lambda_{2}$ & 0.117 & 1.931 & .054 \\
\hline$\lambda_{4}$ & 0.040 & 1.439 & .150 \\
\hline \multicolumn{4}{|l|}{ Adj. $R^{2} \quad .031$} \\
\hline \multicolumn{4}{|c|}{ Services sector (during pandemic) } \\
\hline$\alpha$ & 0.841 & 15.934 & .000 \\
\hline$\lambda_{1}$ & -0.006 & -0.040 & .968 \\
\hline$\lambda_{3}$ & 0.092 & 1.060 & .291 \\
\hline \multicolumn{4}{|l|}{ Adj. $\mathrm{R}^{2} \quad .037$} \\
\hline \multicolumn{4}{|c|}{ Industrial sector (before pandemic) } \\
\hline$\alpha$ & 0.998 & 50.646 & .000 \\
\hline$\lambda_{2}$ & 0.145 & 3.332 & .001 \\
\hline$\lambda_{4}$ & -0.008 & -0.582 & .561 \\
\hline Adj. $\mathrm{R}^{2} \quad .032$ & & & \\
\hline
\end{tabular}




\begin{tabular}{|l|c|c|c|}
\hline Industrial sector (during pandemic) & & & \\
\hline$\alpha$ & 0.960 & 23.071 & .000 \\
\hline$\lambda_{1}$ & 0.241 & 1.409 & .161 \\
\hline$\lambda_{3}$ & 0.031 & 0.276 & .783 \\
\hline Adj. $\mathrm{R}^{2} .056$ & & & \\
\hline
\end{tabular}

\section{DISCUSSION}

Study results indicated that herding was absent before the pandemic and during it at market-level which implies that COVID-19 pandemic did not affect the behavior in the Jordanian stock market. The same results were concluded in the cryptocurrency markets by Yarovaya, Matkovskyy, and Jalan (2020). In stock markets, however, the pandemic has affected herding behavior in the developed markets like Europe (Espinosa-Méndez \& Arias, 2021) and Australia (Espinosa-Méndez \& Arias, 2020). In addition, the pandemic affected herding behavior in emerging markets like the Chinese market (Wu et al., 2020) while in frontier markets, to which Jordanian market belongs, Abdeldayem and Al Dulaimi (2020) claimed that the pandemic has affected herding behavior in the countries of gulf cooperation council. At sector-level, study results also suggested that herding was not affected by the pandemic which is not in line with the results reached by Dhall and Singh (2020) who concluded that COVID-19 pandemic encouraged the formation of herding behavior at sector-level in the Indian stock market and Luu and Luong (2020) who claimed that the pandemic changed herding behavior at sector-level in stock markets of Taiwan and Vietnam. One explanation for the absence of the pandemic effect on herding behavior in the Jordanian market may be the closure of ASE by the government for about 39 days after the announcement of COVID19 pandemic. This closure may have mitigated the pandemic effect on herding because strict governmental procedures were claimed to have a reducing effect on herding behavior during the first three months of 2020 in many countries including Jordan (Kizys, Tzouvanas, \& Donadelli, 2021). Closing ASE during the month after the announcement of the pandemic may have absorbed the shock of the bad news and gave investors more time to see what information are available about the economic consequences of the event.

Study results can be generalized to represent Jordanian stock market and other financial markets that have the same characteristics because the study included all listed companies in all sectors of the ASE that were listed during the covered period. The effect of the pandemic on herding behavior was studied in many countries covering different periods but this study is the first study to test the effect in Jordan for the period from beginning of 2015 to the end of 2020 and it's among first studies to test that effect at industry-level. study results may benefit the investors by providing them with information needed to take investment decision during pandemic like COVID-19. When investors know that the pandemic has no effect on herding behavior, they may not account for the behavior in pricing stocks. The results of the study may also be important to governments and market managements because it provide them with information about what effect their procedures during pandemics may have on herding behavior. Future research may be needed to study the behavior during the pandemic using other measures of herding and covering different periods before and after COVID-19. More studies about herding during the pandemic at sector-level are needed to enhance the understanding of the behavior in different sectors and to determine whether herding in these sectors have the same response to pandemics like COVID-19.

\section{REFERENCES}

Abdeldayem, M.M., \& Al Dulaimi, S.H. (2020). Investors herding behavior and pandemic-risk related in the GCC stock markets. Academy of Accounting and Financial Studies Journal, 24(6), 1-213. Available from https://www.proquest.com

Akinsomi, O., Coskun, Y., \& Gupta, R. (2018). Analysis of herding in REITs of an emerging market: The case of Turkey. Journal of Real Estate Portfolio Management, 24(1), 65-81. Retrieved from https://aresjournals.org/loi/repm 
Altig, D., Baker, S., Barrero, J.M., Bloom, N., Bunn, P., Chen, S., . . Thwaites, G. (2020). Economic uncertainty before and during the COVID-19 pandemic. Journal of Public Economics, 191. doi:10.1016/j.jpubeco.2020.104274

Bakar, S., \& Yi, A.N.C. (2016). The impact of psychological factors on investors' decision making in Malaysian stock market: A case of Klang Valley and Pahang. Procedia Economics and Finance, 35, 319-328. doi:10.1016/S2212-5671(16)00040-X

BenSaïda, A., Jlassi, M., \& Litimi, H. (2015). Volume-herding interaction in the American market. American Journal of Finance and Accounting, 4(1), 50-69. doi:10.1504/AJFA.2015.067837

Campajola, C., Lillo, F., \& Tantari, D. (2020). Unveiling the relation between herding and liquidity with trader lead-lag networks. Quantitative Finance, 20(11), 1765-1778. doi:10.1080/14697688.2020.1763442

Candraningrat, I.R. (2018). Analysis of herding behavior in the Indonesian capital stock market. Proceedings of the 1st Aceh Global Conference, Indonesia. doi:10.2991/agc-18.2019.59

Chang, E.C., Cheng, J.W., \& Khorana, A. (2000). An examination of herd behavior in equity markets: An international perspective. Journal of Banking \& Finance, 24(10), 1651-1679. doi:10.1016/S03784266(99)00096-5

Chaudhary, M., Sodani, P.R., \& Das, S. (2020). Effect of COVID-19 on Economy in India: Some Reflections for Policy and Programme. Journal of Health Management, 22(2), 169-180. doi:10.1177/0972063420935541

Chen, W. (2020). An Examination of Herding Behavior in Chinese A-Share Market by Cross-Sectional Absolute Deviation (CSAD). Modern Economy, 11(04), 785-792. doi:10.4236/me.2020.114058

Christie, W.G., \& Huang, R.D. (1995). Following the pied piper: Do individual returns herd around the market? Financial Analysts Journal, 51(4), 31-37. doi:10.2469/faj.v51.n4.1918

Curto, J.D., Falcão, P.F., \& Braga, A.A. (2017). Herd behaviour and market efficiency: Evidence from the Iberian stock exchanges. Journal of Advanced Studies in Finance, $8\{2(16)\}, 81-93$. doi:10.14505/jasf.v8.2(16).01

Dhall, R., \& Singh, B. (2020). The COVID-19 pandemic and herding behaviour: Evidence from India's stock market. Millennial Asia, 11(3), 366-390. doi:10.1177/0976399620964635

Elshqirat, M.K. (2019). Testing sectoral herding in the Jordanian stock market. International Business Research, 12(8), 88-106. doi:10.5539/ibr.v12n8p88

Elshqirat, M.K. (2020). Ramadan effect on sectoral herding. Independent Journal of Management \& Production, 11(6), 1867-1882. doi:10.14807/ijmp.v11i6.1146

Espinosa-Méndez, C., \& Arias, J. (2020). Herding behaviour in Australian stock market: Evidence on COVID-19 effect. Applied Economics Letters, pp. 1-4. doi:10.1080/13504851.2020.1854659

Espinosa-Méndez, C., \& Arias, J. (2021). COVID-19 effect on herding behaviour in European capital markets. Finance Research Letters, 38. doi:10.1016/j.frl.2020.101787

Gavriilidis, K., Kallinterakis, V., \& Tsalavoutas, I. (2016). Investor mood, herding and the Ramadan effect. Journal of Economic Behavior \& Organization, 132, 23-38. doi:10.1016/j.jebo.2015.09.018

Goodell, J.W. (2020). COVID-19 and finance: Agendas for future research. Finance Research Letters, 35. doi: 10.1016/j.frl.2020.101512

He, P., Sun, Y., Zhang, Y., \& Li, T. (2020). COVID-19's impact on stock prices across different sectors-An event study based on the Chinese stock market. Emerging Markets Finance and Trade, 56(10), 2198-2212. doi:10.1080/1540496X.2020.1785865

Huang, C., Wang, Y., Li, X., Ren, L., Zhao, J., Hu, Y., . . Cao, B. (2020). Clinical features of patients infected with 2019 novel coronavirus in Wuhan, China. The Lancet, 395(10223), 497-506. doi:10.1016/S0140-6736(20)30183-5

Hwang, S., \& Salmon, M. (2004). Market stress and herding. Journal of Empirical Finance, 11(4), 585616. doi:10.1016/j.jempfin.2004.04.003

Hwang, S., \& Salmon, M. (2009). Sentiment and beta herding. UK: Warwick University. 
Kizys, R., Tzouvanas, P., \& Donadelli, M. (2021). From COVID-19 herd immunity to investor herding in international stock markets: The role of government and regulatory restrictions. International Review of Financial Analysis, 74. doi:10.1016/j.irfa.2021.101663

Lakonishok, J., Shleifer, A., \& Vishny, R.V. (1992). The impact of institutional trading on stock prices. Journal of Financial Economics, 32, 23-43. doi:10.1016/0304-405x(92)90023-q

Luu, Q.T., \& Luong, H.T.T. (2020). Herding behavior in emerging and frontier stock markets during pandemic influenza panics. The Journal of Asian Finance, Economics, and Business, 7(9), 147158. doi:10.13106/jafeb.2020.vol7.no9.147

Mahmud, S.F., \& Tiniç, M. (2018). Herding in Chinese stock markets: A nonparametric approach. Empirical Economics, 55(2), 679-711. doi:10.1007/s00181-017-1281-y

Narayan, P.K., Gong, Q., \& Aliahmed, H.J. (2021). Is there a pattern in how COVID-19 has affected Australia's stock returns? Applied Economics Letters, pp. 1-4. doi:10.1080/13504851.2020.1861190

Nasarudin, A.F., Noordin, B.A.A., Law. S.H, Yahya, M.H. (2017). Investigation of herding behaviour in developed and developing countries: Does country governance factor matters? Capital Markets Review, 25(2), 1-14. Retrieved from https://www.mfa.com.my/

Ortmann, R., Pelster, M., \& Wengerek, S. T. (2020). COVID-19 and investor behavior. Finance Research Letters, 37. doi:10.1016/j.frl.2020.101717

Qasim, M., Hussain, R., Mehboob, I., \& Arshad, M. (2019). Impact of herding behavior and overconfidence bias on investors' decision-making in Pakistan. Accounting, 5(2), 81-90. Retrieved from http://www.growingscience.com/ac/ac.html

Rahman, R.E., \& Ermawati, E. (2020). An analysis of herding behavior in the stock market: A case study of the Asean-5 and the United States. Bulletin of Monetary Economics and Banking / Buletin Ekonomi Moneter Dan Perbankan, 23(3), 297-318. doi:10.21098/bemp.v23i3.1362

Sharma, S.S. (2020). A note on the Asian market volatility during the COVID-19 pandemic. Asian Economics Letters, 1(2). doi:10.46557/001c.17661

Sias, R. (2004). Institutional herding. Review of Financial Studies, 17(1), 165-206. doi: $10.2139 /$ ssrn. 307440

Ventosa-Santaularia, D. (2009). Spurious regression. Journal of Probability and Statistics, 2009. doi: $10.1155 / 2009 / 802975$

World Health Organization. (2020). WHO announces COVID-19 outbreak a pandemic. Retrieved from http://www.euro.who.int/en/health-topics/health-emergencies/coronavirus-covid19/news/news/2020/3/who-announces-covid-19-outbreak-a-pandemic

World Health Organization. (2021). Corona virus disease pandemic. Retrieved from https://www.who.int/emergencies/diseases/novel-coronavirus2019?gclid=EAIaIQobChMI79Dpxpv-7gIVGPjICh2jhADMEAAYASAAEgLw6fD_BwE

Wu, G., Yang, B., \& Zhao, N. (2020). Herding behavior in Chinese stock markets during COVID19. Emerging Markets Finance and Trade, 56(15), 3578-3587. doi:10.1080/1540496X.2020.1855138

Yarovaya, L., Matkovskyy, R., \& Jalan, A. (2020). The effects of a "black swan" event (COVID-19) on herding behavior in cryptocurrency markets. Journal of International Financial Markets, Institutions and Money. doi:10.1016/j.intfin.2021.101321 